\title{
SELECTED ASPECTS OF NATURAL PROCESSES IN URBAN PARKS ON THE EXAMPLE OF THE ŁAZIENKI PARK IN WARSAW
}

\section{INTRODUCTION}

The areas of urban greenery are the subject of interest for numerous disciplines. The present report belongs to the landscape-and-geochemical direction, developing within the borderland of physical geography and chemistry.

The study of geochemical landscape concerns the natural processes, which associate the components of landscape. These components are being considered in the vertical setting (bedding, soil, vegetation, waters, the lower layers of the atmosphere) and in the horizontal one (in terms of the spatial complexes). The primary spatial units of the geochemical landscape are:

- the eluvial surfaces (uplands), characterised by the losses of matter;

- the transit surfaces (slopes), through which the matter is transported;

- the superaquatic surfaces (lows, such as valleys), being the places of accumulation of the matter.

In the anthropogenic landscapes the landscape components and the natural processes are undergoing modification.

The object of study, reported here, was constituted by the Łazienki Park, located in downtown Warsaw. The park has 76 hectares of area. It is located within the Valley of Middle Vistula (80\% of the Park's area) and the Warsaw Plain, these two units being separated by the Warsaw Escarpment.

\section{THE OBJECTIVES AND THE METHODS OF STUDY}

The objective of the study reported was to identify the components of the landscape of Łazienki and the process taking place between them. An attempt was also made of assessing the kinds of hazards to natural environment originating from human activity. The observations conducted concerned:

- grounds and soils (selected physical and chemical properties);

- waters (measurement of the groundwater table level, chemical composition of the groundwater and surface water, as well as snow); 
- vegetation (assessment of the degree of transformation of the tree stands);

- deposition of dust.

\section{RESULTS}

\section{The eluvial surface}

The eluvial surface is located in the western part of the Park. It is a plain elevated by more than 30 metres above the "zero" level of Vistula river, that is - more than $100 \mathrm{~m}$ a.s.l., built of sands and clays of fluvio-glacial origin. It is characterised by the fertile and weakly permeable bedding, and the compact, managed vegetation cover composed largely of the native species. The water-bearing layer is broken here by the belt of the uplifted Pliocene silts. In some places local levels of suspended waters developed, for instance - at the depth of $9 \mathrm{~m}$ below the surface.

There are also places where the surface matter has anthropogenic character (sand, gravel, débris). For purposes of reclamation these areas were covered with a significant thickness of humus. The artificial black earths thereby created contain a lot of organic carbon, up to $2 \%$ (i.e. more than $3 \%$ of humus). In cases when a habitat with a transformed bedding is overgrown with the managed loose greenery, soils are enriched with the nutrients through application of mineral and organic (peat, stable manure, bark) fertilisers. These manipulations, accompanied by watering and turning over, establish advantageous conditions for the intensive development of the soil organisms. The organisms gradually penetrate to the increasingly deep layers of the soil, mix it and break up organic waste, thereby enriching the soil in amorphous humus (contained, in particular, in the coprolites). Owing to the fertile bedding, the process of soil enrichment proceeds quicker. Biological accumulation is insignificantly limited by the mowing of grasses and raking of leaves. A part of the matter accumulated in this landscape moves into the lower landscapes. This is made possible by the precipitation, which, by infiltration, washes out the soluble compounds.

Chemical properties of snow

Table 1.

\begin{tabular}{|c|c|c|c|c|}
\hline $\begin{array}{c}\text { Length of snow } \\
\text { deposition }\end{array}$ & $\begin{array}{c}\text { Distance from } \\
\text { the street }\end{array}$ & $\mathrm{mg} / \mathrm{l} \mathrm{of} \mathrm{Na}{ }^{+}+\mathrm{K}^{+}$ & $\mathrm{mg} / \mathrm{l} \mathrm{of} \mathrm{Cl}^{-}$ & $\mathrm{mg} / \mathrm{l} \mathrm{of} \mathrm{SO}_{4}{ }^{2^{-}}$ \\
\hline \multirow{2}{*}{26 days } & $50 \mathrm{~m}$ & 14.9 & 24.8 & 2.3 \\
\cline { 2 - 5 } & $450 \mathrm{~m}$ & 7.3 & 10.6 & 0.9 \\
\hline \multirow{2}{*}{58 days } & $50 \mathrm{~m}$ & 31.8 & 56.7 & 3.9 \\
\cline { 2 - 5 } & $450 \mathrm{~m}$ & 3.5 & 10.6 & 2.6 \\
\hline
\end{tabular}


In the winter season, an intensive accumulation of the salts used against snow and ice on the streets takes place in the soils of the western part of the Park (Table 1). Close to the streets adjacent to the Park the content of $\mathrm{Cl}^{-}$in the snow deposited during 58 days was $57 \mathrm{mg} /$ litre, and of $\mathrm{Na}^{+}+\mathrm{K}^{+}-$ $32 \mathrm{mg} /$ litre. The respective values were smaller by half in the central part of the Park. Waters from the melting snow move downwards to the valley part of the Park, where the elements concentrate in the soil and in the plants.

\section{The transit surface}

The transit surface is constituted by the edge of the upland, sloping down towards the valley at the angle of $32-20^{\circ}$. This surface is cut through by numerous gullies, whose shapes have been remodelled due to construction of paths and roads. The vegetation covering the escarpment, i.e. the managed compact greenery with domination of the black locust, having well-developed root systems, slows down the process of soil erosion. There are no distinct anthropogenic admixtures in the bedding, and the soils are medium fertile and medium permeable. Water sources appear on this area. Waters from the deeper Quaternary aquifers located within the upland flow out of the terrace structures. Their chemical composition undergoes a steady worsening (see Fig. 1). It is only the concentration of the sulphates that decreases, which may be the effect of the decreased imissions of sulphur dioxide in Warsaw.

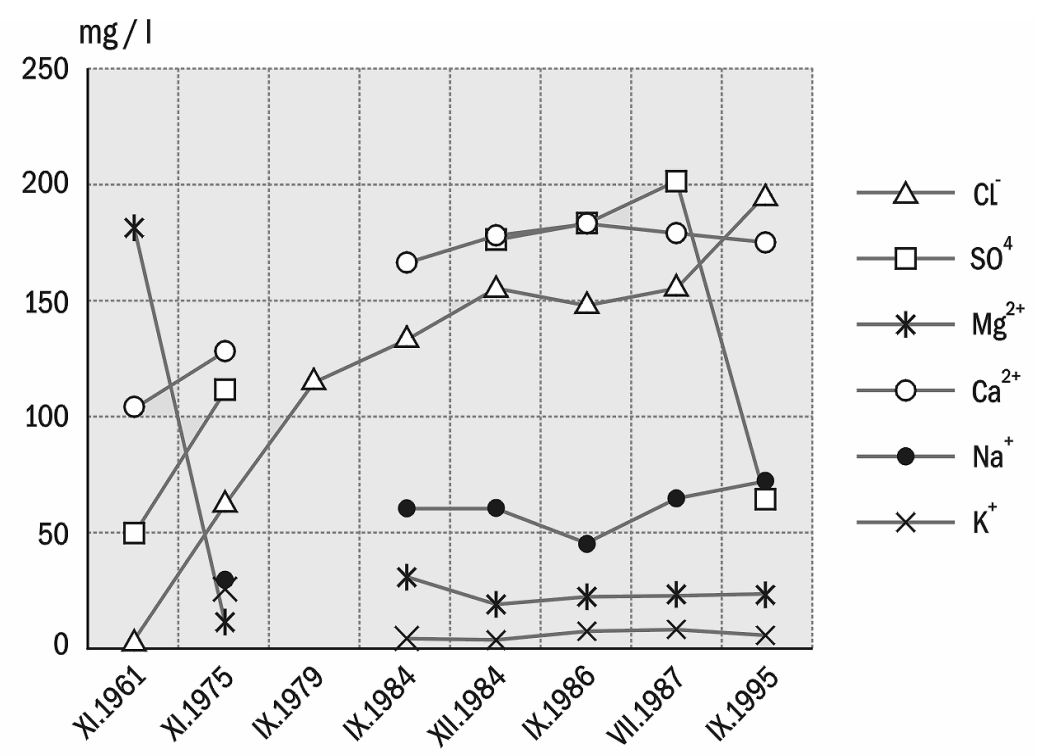

Fig. 1. Concentration of ions in water from Agrykola source in the years 1961-1995 (in mg per litre). Source: Aktualna ocena...,1987. 
Thus, in 1994 the concentration of sulphur dioxide in the air in Warsaw did not exceed the admissible limit (Rocznik..., 1995). Thereby, the volume of sulphates introduced into the groundwater of the first level, due to infiltration of the precipitation waters, decreased.

\section{The superaquatic surface}

The valley part of the Park (the superaquatic area), with elevation of 7.2 to $10.2 \mathrm{~m}$ above the "0" level of Vistula river (i.e. 85.1-88.1 m a.s.l.), is composed of fluvial and lacustrine deposits: sands of various granulation, and, closer to the edge of the upland - also silts with humus and peaty silts. Groundwater appears at the depth of 1 to $2.4 \mathrm{~m}$ below surface in the central part of the Park, and its level drops towards the borders of the Park, mainly towards the north-east, reaching there $3 \mathrm{~m}$ below surface, and even more. This landscape includes three ponds connected through a system of canals. The groundwater, appearing at the depth of 2 to 3 metres, is supplied with the surface and ground water flows from the side of the upland. The supply from the side of the precipitation water has the smallest share, as can be concluded from the lack of seasonal variations of the water level (less than $10 \mathrm{~cm}$ ). Brown soils developed on the strong clayey sands. Conform to the biotope a fragment of a natural wet deciduous forest grows there. The share of alien species ranges between 18 and 30\%. The developed undergrowth and the old tree stands, as well as the shading of the ground, are advantageous for the intensive accumulation of biomass and the activity of soil organisms. In places, where groundwater appears at the depth of 1.5 to $2 \mathrm{~m}$, on the light clayey sands, the degraded black earths developed. Their humus level contains $1.7 \%$ of organic carbon, and displays a high degree of saturation with the bases. Due to the little intensive gardening work (solely raking of leaves) and the rich structure of the preserved deciduous forest, circulation of the matter takes place without significant disturbances and changes. These conditions entail an increase of stability of the ecological system. Yet, this area is subject to an intensive deposition of dust (Fig. 2). Annual deposition of dust amounted in 1996 to $151 \mathrm{~g}$ per sq. $\mathrm{m}$. The highest values of the dust deposition in the summer and autumn seasons are observed in the central (valley) part of the Park. Thus, in July, the total deposition of dust between the centre of the Park and the eastern fringe was above $30 \mathrm{~g}$ per sq. $\mathrm{m}$ (while the admissible monthly norm is at $16.6 \mathrm{~g}$ per sq. $\mathrm{m}$ ). The high deposition level was presumably the cause of the exceptionally high contamination of soils with heavy metals in the central part of the Park. The concentration of Zinc was there, for instance, at $180 \mathrm{ppm}$, the level, which is toxic for plants.

The threat to trees and soil does not only come from the atmosphere, but also from the waters. A significant part of pollution penetrates by means of hydrological migration. A worsening of the state of surface waters, supplying the groundwater, is being observed in the Łazienki Park (Table 2). The main cause of this phenomenon is the direct uptake of water from Vistula river, 


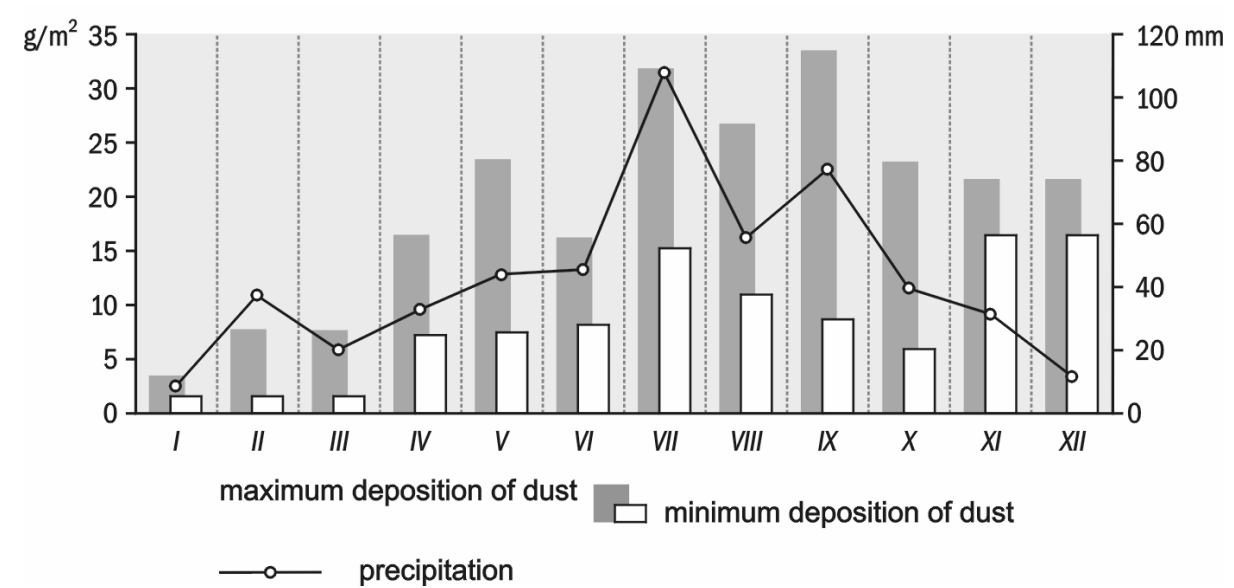

Fig. 2. Minimum and maximum deposition of dust and precipitation in the Łazienki Park in 1996.

heavily polluted with faecal and industrial waste. Chemical composition of surface waters of the Łazienki Park, and of the groundwater supplied from the surface, will not improve unless the main source of water for the ponds is changed (e.g. by tapping deep aquifers), since these shallow reservoirs have a limited self-purification capacity (Aktualna ocena..., 1987).

The tree stands underwent a significant transformation in the central and southern parts of the Park. The vegetation cover is dominated here by the compact managed greenery and the lawns. Among the alien tree species the coniferous trees dominate, which are little resistant to environmental pollution. They also contribute to the lowering of the $\mathrm{pH}$ value of the top soils surface layers, which further lowers the buffer capacity of the habitat. Such a specie composition of the vegetation limits, as well, the regeneration capacity of the vegetation at the instance of stopping of the gardening work in the Park. It is hard to predict how long yet the buffer systems of the landscape will be able of countering the effects of the pressure originating both from the atmosphere and from the hydrological migration.

Table 2.

Comparison of the measurements of ion concentrations in the water of the Northern Pond in August 1987 and September 1995

\begin{tabular}{|l|r|r|r|r|r|r|}
\hline \multirow{2}{*}{\multicolumn{1}{|c|}{ Measurements }} & \multicolumn{6}{|c|}{ Concentrations in mg/litre } \\
\cline { 2 - 7 } & $\mathrm{SO}_{4}^{2-}$ & $\mathrm{Cl}^{-}$ & $\mathrm{Ca}^{2+}$ & $\mathrm{Mg}^{2+}$ & $\mathrm{Na}^{+}$ & $\mathrm{K}^{+}$ \\
\hline Northern Pond, August 1987 & 63.0 & 177.3 & 93.1 & 7.8 & 75.0 & 10.0 \\
\hline Northern Pond, September 1995 & 28.1 & 200.5 & 69.7 & 15.8 & 108.0 & 5.5 \\
\hline
\end{tabular}

Source: Aktualna ocena..., 1987, and own research. 


\section{SUMMARY}

Observations carried out within the area of the Łazienki Park in Warsaw indicate the existence of the following regularities:

- at the mesoscale: natural exchange of matter between the components of landscape and its spatial units has been preserved; this means that the pollution deposited on the autonomous surface is a constant threat to the superaquatic areas, and especially to those in the valley; this regularity concerns both pollution originating from the atmosphere and from the soils;

- at the microscale: the structure of the landscape components displays a significant local differentiation; this differentiation is the result of the purposeful human action and affects the vertical circulation of matter in the landscape, and on its buffering capacities; the share of areas with strongly transformed components is, however, relatively limited;

- the regularities observed in the course of natural processes taking place in the Łazienki Park can be extrapolated to the area of bigger landscape units, as well as other parks of a similar history, located in the river valleys.

\section{REFERENCES}

Aktualna ocena zagrożenia środowiska przyrodniczego Parku Eazienkowskiego oraz ustalenie wytycznych do pielegnowania parku, 1987 [Current evaluation of the hazard to the natural environment of the Eazienki Park and establishment of the directives for the management of the Park; in Polish], PPZ "EL-GE-REW" POL-FRANCE, Warszawa.

Mapa gleb. Park Łazienkowski, skala 1:1000, 1987, [Soil map. Łazienki Park, scale 1:1000; in Polish], elaborated by J. Borzyszkowski, PPZ "EL-GE-REW" POL-FRANCE, Warszawa. Rocznik Statystyczny Warszawy, 1995, [Statistical Yearbook of Warsaw; in Polish], WUS, Warszawa. 